\title{
AOR
}

Selected Papers of \#AolR2020:

The 22nd Annual Conference of the

Association of Internet Researchers

Virtual Event / 13-16 Oct 2021

\section{DIGITAL SITES OF PROTEST: FARMERS' PROTEST IN INDIA AND THE CONSTRUCTION OF A COLLECTIVE IDENTITY ON FACEBOOK}

Anand Badola

Digital Media Research Centre, QUT

\section{Research Issue}

This paper looks at digital sites of protest and platform affordances, through which uninformed or unaware hyper-individualised publics are brought in by the protest community to help construct a collective identity. It examines the ongoing farmers' protest in India and a Facebook page that was specifically created by the protest community called, Kisan Ekta Morcha (Farmers Union Front, herein KEM) and how it is able to create a common collective identity despite the cultural and linguistic differences in India.

\section{Background}

In September 2020, the Indian government passed a set of farm laws, which have a pro-market leaning. While the nature of the passing of the bills is debated, largely it is seen as a controversial move, as the bills were passed without proper consultation with the farmers community. In November 2020, various farm unions in India called for a march to the national capital, New Delhi but the central government used excessive police force to stop them from entering. Since then, the farmers have occupied three borders surrounding the national capital. It is a dynamic protest which has seen both support and vilification in the form of narratives via mainstream and social media. The farmers' community, to create a sympathetic narrative to their own cause, set up a Facebook page called KEM in November. The Facebook page has around five hundred thousand followers and gives daily updates via photos, statuses and videos about the farmers protests.

While the debate around social media and their effectiveness in offline protests revolves around their use as an innovative means of communication, and mobilisation, leading to collective action (Howard \& Hussain, 2013) some claim that digital activism has really no hard influence on offline activism (Morozov, 2011). Others have argued that social media platforms are often used by activists to amplify participation in contentious politics (Earl \& Kimport, 2011; Lim, 2013; Valenzuela, 2013), signifying the potential of social media platforms to aid social movements and protests. Tufekci and Wilson (2012), in

Suggested Citation (APA): Badola, A. (2021, October). Digital Sites of Protest: Farmers' Protest in India and the Construction of a Collective Identity on Facebook. Paper presented at AolR 2021: The 22nd Annual Conference of the Association of Internet Researchers. Virtual Event: AolR. Retrieved from http://spir.aoir.org. 
this regard, have argued that social media are distinct as they help create interpersonal connections, which leads to a networked chain of personalised collective action - a connective action (Bennett and Segerberg, 2012). Boulianne et al. (2020), while comparing traditional media (television news) and social media, argue that social media are distinct in creating awareness as they expose unaware publics not only to details about the protest's events but also to invitations to participate in such activities. This paper contributes to these debates as it looks at the way platform affordances can be used to construct a collective identity that a broader public can identify with.

\section{Methodology}

Focusing on the Facebook page KEM, the paper examines how protest campaign pages like these constructs both a collective identity and narrative of protests. Using textual and visual analysis, the paper focuses on audio-visual posts on this page with extended captions describing personalised experiences of the farmer protests and helping in the construction of the collective identity. Expanding on the methodological framework employed by Khazraee \& Novak (2018), the paper focuses on platform affordances related to discursive practices and the digitally mediated performances of the farmer protests. Discursive affordances are used to frame issues in such a way to construct shared meanings and collectively negotiate those meanings. The discursive practices also include the sharing of personal anecdotes, which has the potential to resonate with the larger digital public.

Performative affordances focus on the enactment of protests, which is portrayed through visual imagery in the form of photos and videos. The photos and videos are intentionally emotional and visceral to convey the broader message to the public and create empathetic support for the farmers' protest. These digital performative acts are possible because of the platform affordances of Facebook which invites its users to not only participate in collective action but also share these posts across other social media platforms. Facebook's affordances, especially 'reactions' metrics with care, anger, love as responses, have a community building imprint as it promotes an emotional connection with the posts and the page. While on Twitter, too, one can post photos and create threads as discursive flows to give updates about a particular protest, a Facebook page provides a stronger framing structure as both visual imagery and narrative posts weave together in a dedicated space, which helps in creating a collective identity.

\section{Preliminary Findings}

The KEM has been relatively successful in garnering support among various sections of the people as the Indian government temporarily got the Facebook page banned for allegedly promoting 'anti-national' activities. The audio-visual imagery has resonated with people and a strong sentiment in support of the farming community. The images, the flags, and the slogans used in this page are seen in the offline community of protesters as cars and people are seen displaying the same flags and slogans. 
This is even despite substantial differences ranging from class, caste, linguistic, and religious differences in the farmers community as well as among its supporters. The Publics engage in different languages on the same Facebook page (mainly Punjabi, Hindi and English). Images on the page show cross-regional and cross-cultural publics coming together and forming a united stand against the farm laws.

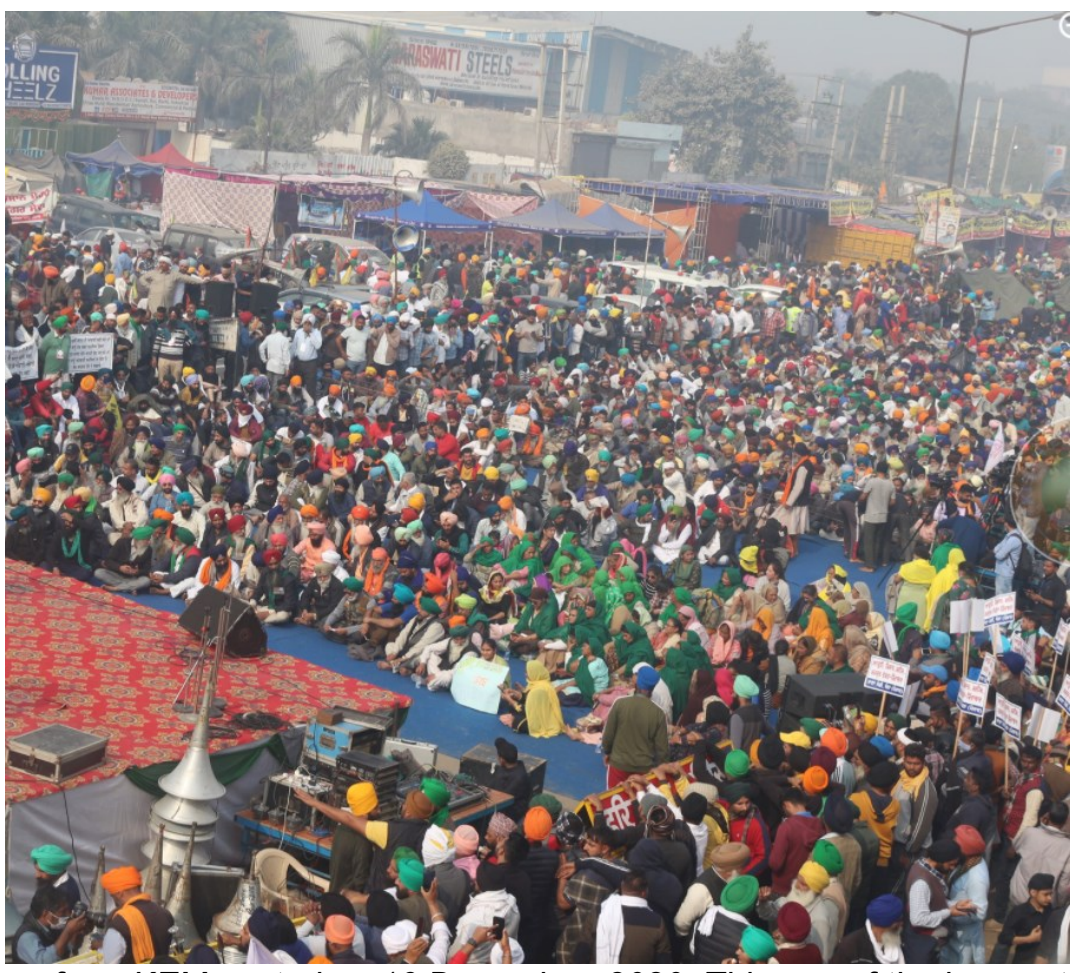

One of the images from KEM posted on 16 December, 2020. This one of the key protest sites near the borders of New Delhi. Source: Kisan Ekta Morcha Facebook Page

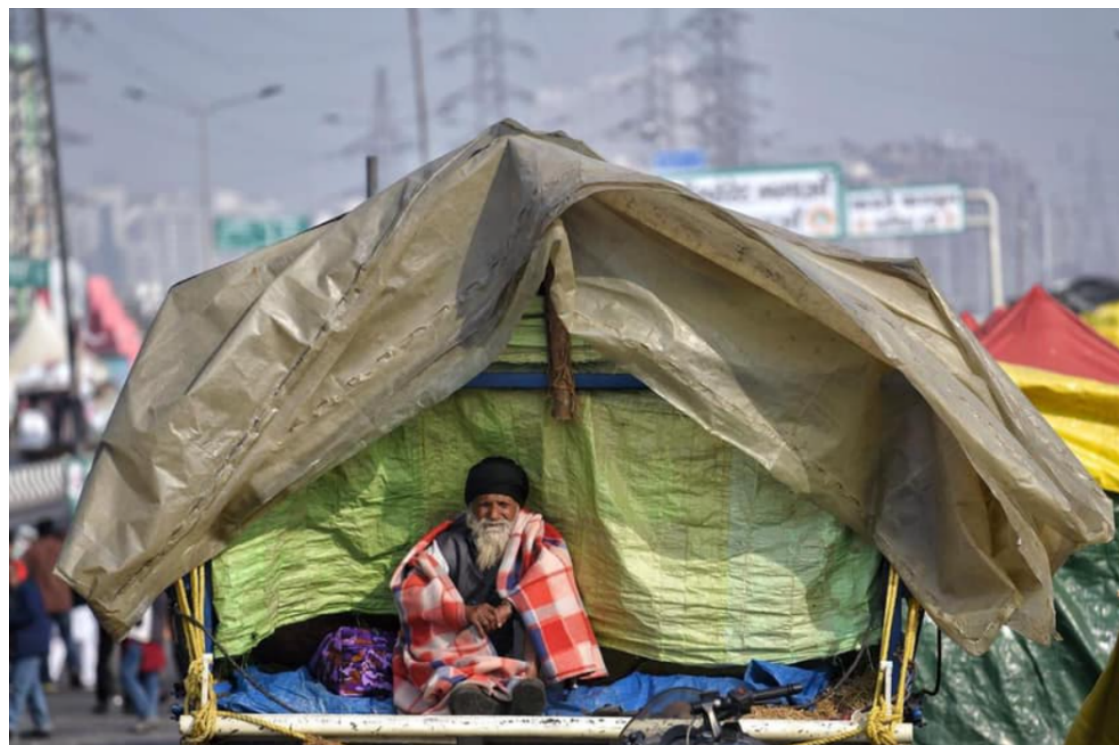

A farmer's temporary home in a 'tractor'. There are thousands of such makeshift homes at the protest sites. Source: Kisan Ekta Morcha Facebook page. 


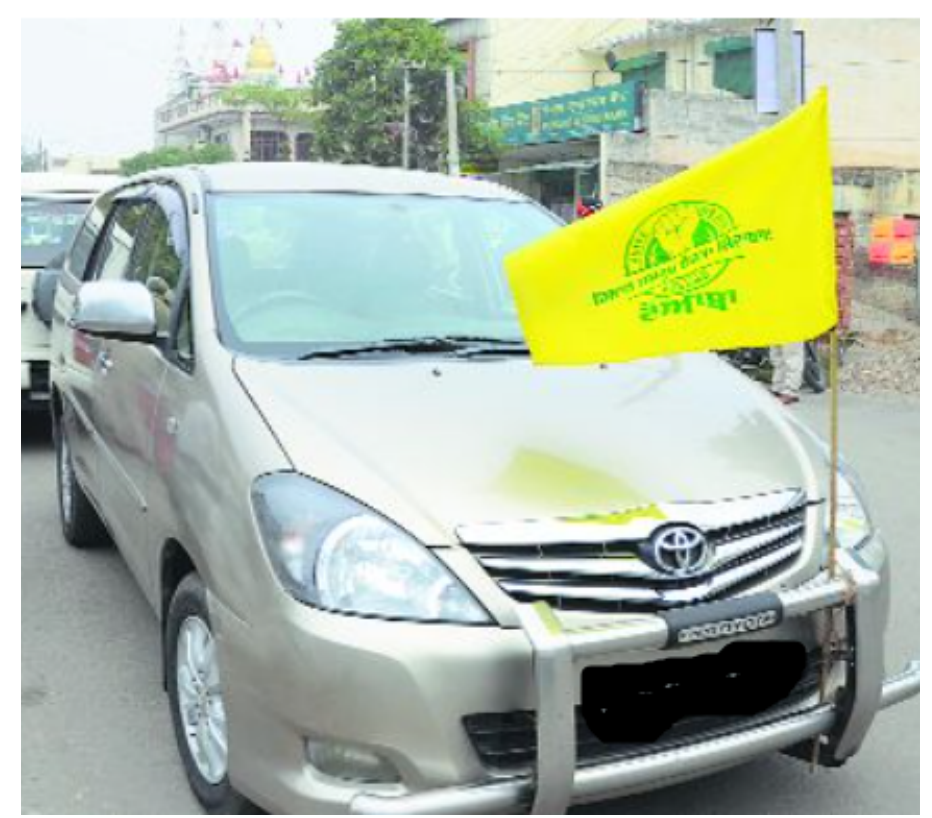

One of the many people supporting the farmers protest by putting flags on their cars. There are also slogans painted on cars as a sign of support. Many of the slogans and flags are directly taken from the KEM Facebook page. Source: The Tribune India

\section{Further Outlook}

Considering the longevity of the farmers protest, the next step in this study is to look at how social media can help sustain a protest. I will look at other social media handles of KEM (for instance Twitter) and analyse their activity. While this study solely focuses on the Facebook page of KEM but to fully grasp the way a protest movement utilises social media platforms is to analyse their activities across platforms, which makes room for further work.

The farmers protest is an ongoing event and the researcher continues to monitor the Facebook page as the situation changes. This case study is part of a larger debate about the role of social media in protest movements and also serves as a response to Morozov's critique. The paper contributes in our understanding of ongoing protests in a diverse country like India and how multicultural publics are brought tougher via social media to engage collectively in contentious politics.

\section{References}

Bennett, W. L., \& Segerberg, A. (2012). The Logic of Connective Action: Digital Media and the Personalization of Contentious Politics. Information, Communication \& Society, 15(5), 739-768. https://doi.org/10.1017/CBO9781139198752

Boulianne, S., Koc-Michalska, K., \& Bimber, B. (2020). Mobilizing media: Comparing TV and social media effects on protest mobilization. Information, Communication \& Society, 23(5), 642-664. https://doi.org/10.1080/1369118X.2020.1713847

Earl, J., \& Kimport, K. (2011). Digitally enabled social change: Activism in the Internet age. MIT Press. 
Emad, K., \& Novak, A. N. (2018). Digitally Mediated Protest: Social Media Affordances for Collective Identity Construction. Social Media + Society, 4(1). http://dx.doi.org/10.1177/2056305118765740

Howard, P. N., \& Hussain, M. M. (2013). Democracy's fourth wave? Digital media and the Arab Spring. Oxford University Press.

Lim, M. (2013). Framing Bouazizi: 'White lies', hybrid network, and collective/connective action in the 2010-11 Tunisian uprising. Journalism: Theory, Practice \& Criticism, 14(7), 921-941. https://doi.org/10.1177/1464884913478359

Morozov, E. (2011). The net delusion: The dark side of internet freedom (1st ed). Public Affairs.

Tufekci, Z., \& Wilson, C. (2012). Social Media and the Decision to Participate in Political Protest: Observations From Tahrir Square. Journal of Communication, 62(2), 363-379. https://doi.org/10.1111/j.1460-2466.2012.01629.x 